\title{
Customer Orientation and Marketing in Containerized Freight Distribution and Logistics - Perspectives of the Czech Republic
}

\author{
Jirsák, P., Kolářr, P.
}

The objective of this research is to analyze the customer service orientation and policy of Czech logistics providers (3PLs), global shipping lines and multimodal transport operators (MTOs). Evaluating customer orientation in the market of transport and logistics is a highly complex task. To obtain the data necessary for an informed analysis, open interviews will be made and questionnaires will be distributed to the relevant companies' managers in the Czech Republic. Due to the concentration of container and logistics activity within the relatively small number of important market players active in the country's market, the approach of market characteristics will be case study based. Moreover, the research will offer an important analysis of the shipping lines' and logistics providers' services in terms of customer service policy in the Czech Republic. If possible and feasible given the data, a survey of customer perspectives will also be undertaken. The conceptual part of the paper focuses on a literature review, methodology and anticipated results only.

JEL classification: L91, M16, M31

\section{Marketing Literature and Customer Orientation in the Shipping Industry}

A customer or marketing orientation in the shipping industry is based on the concept that places the shipper (customer) first with all steps taken affecting the customer relationship. In the shipping market, the marketing models or concepts are not generally applied through the shipping lines' programs and strategies (Brooks, Lings and Botschen, 1999; Sato, 2002). It is highly difficult to find marketing orientation throughout the shipping companies, making marketing itself not always successful. However, customer orientation itself in the markets has been widely applied in the discipline of marketing (Steinman, Deshpande and Farley, 2000). The term 'customer oriented company' is used to deal with the company's knowledge of its customer needs and how responsive the company is to them in terms of value creation and delivery (Berger et al., 2002; Gummesson, 2002). On the other hand, marketing definitions, models and concepts are lacking in the shipping industry and the area of freight distribution (Murphy, Daley and Hall, 2000; Plomaritou, 2006).

It is a complex task to set the position of the international freight forwarders - the key intermediaries in international trade in goods; they are trade specialists providing a variety of functions to facilitate movement of cross-border shipments (Murphy and Daley, 1996). Their main advantage is to decide if it is better to ship the goods directly with a carrier or if it is more economical to consolidate. In terms of contract of carriage, the freight forwarder is an agent; based on the freight forwarder agreement, the forwarder is a service provider. The company acts as an agent arranging for the shipment of goods belonging to his customer. In addition, the company can sometimes also act as the shipper and principal contractor arranging the carriage in his own name (Novák et al., 2011). Regardless, acting as a principal agent, the freight forwarder tries to contract out as much responsibility as possible, sometimes resulting in quite confusing standard trading conditions. All things considered, the role of the freight forwarder is dual (Leung, 2007).

Considering the shipping industry in terms of liner shipping (container shipping), the discipline of business-to-business marketing (B2B) is the science dealing with shippers' needs for the carriage of goods by sea, including satisfaction with "door-to-door" services. Determining the level of satisfaction requires an analysis of the market to understand and forecast correctly a shipper's transport needs, appropriate organization, planning and control of the shipping line's means (Plomaritou, 2006). 
Based on the customer's (shipper's) perspectives, strong business relationships cannot be developed without an assessment of the value created and delivered by the company. The nature of liner shipping services determines the importance of positions by the service provider (the shipping line) and the shipper (customer). They are higher compared to the marketing of physical goods and indivisible. Every interaction between the shipping line and the shippers affects the quality of the services and the benefits provided (Plomaritou, Plomaritou and Giziakis, 2011). In the shipping industry, the following basic types of interaction can be found:

- Interaction between the shipper and the service facilities, such as the formation of the bill of lading (basic transport document) by electronic means (EDI system),

- Interaction between the shipper and other shippers,

- Interaction between the shipping line such as a staff member and the shipper.

Marketing orientation is not achieved unless all members of the staff understand the functions of marketing and what it really means in terms of their own responsibilities. There are two ways we can view the importance and role of marketing: the task involved in the marketing process can be either set, or we can search for the goals of marketing based on the particular market conditions.

Customer orientation must place the shipper at the center of the shipping line's actions; in other words, the company must be close to the shipper, making him the fundamental point of the marketing concept. All staff needs to be aware of the options in which they can increase customer satisfaction, despite having just indirect contact with the customer (for instance, the employees of intermodal planning or accounting department). Moreover, the service quality and customer claims must be analyzed and discussed at all management levels, making space for process improvements within the company. All activities of the shipping line must be implemented within the scope of a philosophy based on efficient and responsible marketing (Plomaritou, 2006). The combination of shipper requirements for frequent services at low rates and the aim of the shipping lines (carriers) to reduce costs by achieving economies of scale with the introduction of new higher capacity vessels led to a negative financial outcome for the maritime transport industry together with issues in terms of customer orientation. Moreover, an increase in the excess supply of deployed container vessels' capacity, strong market competition and rising fuel prices represent issues which the global shipping industry and its customers have to face in general, both globally and regionally.

\section{Customer Orientation of Logistics Providers}

Logistics services represent quite a significant market. For instance, logistics providers gained revenues of USD 162.3 billion in 2009 in the European market, and USD 165.1 billion in 2010. Furthermore, 46 percent of logistics expenditures are dedicated to outsourcing of logistics services. In 2010, the most outsourced logistics services were international transport (91 percent), domestic transport (77 percent) and warehousing (61 percent) (Langley, 2012).

The customer orientation of logistics providers is of relevance to the competitive advantage needed in the increasingly competitive market of logistics providers. Tough competition is caused by saturation of the logistics service market as well as by customer requirements. Customers such as production and service companies intensify pressure on logistics providers due to the necessity to increase the level of logistics service and reduce costs.

For instance, each organization should consciously work on establishing a marketing strategy, enabling them to keep and develop customer loyalty (Christopher, Payne, Ballantyne, 2002). A satisfied, loyal customer is the best barrier and protection against competitors. Concerning the aforementioned extent of outsourced logistics services, there are obviously a few companies with no or little experience in logistics outsourcing. Hence, developing marketing strategies - especially with a focus on customer loyalty - becomes even more significant for logistics providers.

Customers that have already gained experience cooperating with logistics providers are more demanding and require a higher level of logistics service and better customer orientation than in previous contracts. Moreover, it is highly important to realize that gaining a new customer is more costly than retaining an old one; in addition, this benefit is intensified by the higher probability of increasing frequency and purchase value associated with the old customer rather than with a new one e.g. (Christopher, 2005). Thus, it is highly important to consider customer loyalty within the establishment of marketing strategy of a logistics organization. An increasing but still insufficient number of works has recently been dedicated to customer loyalty to logistics providers and factors that affect the rate of customer loyalty.

Customer loyalty could be appraised by various aspects. However, the following ones are among the most basic:

- Retention - customer willingness to prolong a contract of the same scope with the same logistics provider,

- Expansion - customer willingness to increase the scope of business with a particular logistics provider,

- Referrals - willingness to share world of mouth about customer satisfaction with a particular logistics provider. 
Cost and performance improvement, length of contract and logistics service complexity were analyzed regarding their impact on customer loyalty. Only cost and performance improvements provided a positive contribution to customer loyalty; a similar magnitude to all three corner stones (retention, expansion, referrals) was identified (Wallenburg, 2009). No difference between cost and performance contribution was uncovered. Hence, a passive response to a customer request about changes in logistics services or costs would not lead to sufficient customer loyalty either in retention or in expansion and referrals aspects.

The complexity of outsourced logistics service and length of contract were identified as significant factors leading to proactive cost and performance improvements in the research of e.g. (Wallenburg, 2009).

Outsourcing of complex logistics services is commonly based on long-term contracts (over 36 months). In a longtern outsourcing relationship, performance improvements have a better impact on customer loyalty than on cost improvement. On the other hand, a logistics company providing a narrow range of service, of which quality is easily imitated, has to compete more on price. Moreover, contracts for such services are commonly signed for shorter term periods in comparison to complex service ones.

Furthermore, both the customer and the logistics provider should consider their mutual ability to adopt specific requirements, such as warehouse locality, ICT, human resources and their absorption, monitoring and assessment of performances etc. When a provider is willing to accept and adopt such customer specifics, it has a significant and highly positive impact on customer loyalty and perception of the purchased logistics services (Large, 2011).

Specific investments of providers into human resources, long-term assets and procedures lead not only to higher credibility and reliability for the provider but also higher trust of the outsourcing arrangement by the customer (Ganesan, 1994).

However, when a customer has to adapt to such specific provider requirements, customer satisfaction with the outsourcing relationship is negatively influenced to a significant degree. Nonetheless, the impact on customer loyalty is still positive, as a customer is more involved in such an outsourcing relationship due to his high investments.

Another, as yet unmentioned, factor affecting customer loyalty is the price of the logistics service, which is appraised by customers regarding expected price as well as the expected and actual level of logistics performances provided to them. The impact of price satisfaction, service satisfaction and outsourcing relationship satisfaction on customer loyalty was analyzed by, for example, Cahill et al. (2010a). The relationship between logistics service satisfaction and customer relationship satisfaction was researched by e.g. Caceres and Paparoidamis (2007) and a positive affect was proven.

Researchers, such as Cahill et al. (2010a) did not prove that price would have a significant impact on customer loyalty; the same output is also given by others, e.g. Stank et al. (2003). However, the conclusion that price is no longer important for customer decision making would be wrong. The reason for this is that acceptable price has become a qualification but it is not a decisive criterion. This corresponds to the magical tetragon model described by some authors, e.g. Pernica (2005). Such a model identifies a shift of competitive advantage from price to responsiveness and individualization.

According to Cahill et al. (2010a), the quality of logistics services - including both tangible (delivery time, picking accuracy, on-time delivery, etc.) and social aspects (interaction, communication, cooperation, etc.) - has the most significant impact on customer loyalty, particularly on customer retention. Besides the quality of logistics services, two other factors were analyzed: satisfaction with price and satisfaction with the outsourcing relationship.

Some authors, e.g. Davis and Mentzer (2006), cited that customer satisfaction and loyalty are more influenced by relationship factors (i.e. communication and handling problems) than operational factors (i.e. on time, in-full, error-free delivery).

Customer loyalty is also affected by the asymmetry of the customer-provider relationship. In the event that the asymmetry is based on the better negotiation power of a customer over a provider (supplier provides insignificant volume of logistics services to a customer and the services have a simple nature and could thus be sourced from a different supplier without additional substantial transaction costs), "adequate service level" (the minimum accepted by the customer) is shifted to the upper level and so the toleration zone (difference between desired and adequate service level) shrinks and thus a provider has limited space for variability of service level. Moreover, a provider subjectively raises customer expectations and so it is reflected in the level of logistics services provided.

When a customer is in a subordinate position (significant volume of logistics services is provided by this provider and there are high transaction costs associated with changing providers), "adequate service level" is lowered and the provider accordingly adjusts customer service. A logistics provider subjectively lowers customer service expectations and the customer is provided with a lower level of logistics services than expected e.g. (Davis, Mentzer, 2006).

A customer and provider that are involved in an outsourcing relationship - intended to develop customer loyalty in retention, extension and referrals - should have consensus about particular elements of the logistic service (Reliability, 
Communication, Timeliness, and Responsiveness). Hence, reduction of the gap between customer expectations and the provided logistics performance is achieved.

It has already been stated that level of logistics service has a significant positive impact on customer loyalty. The question to be asked is whether the logistics company should provide the customer's expected level of service or exceed it in order to establish customer loyalty. This issue was researched by e.g. Cahill et al. (2010b); the following findings were given: exceeding the targeted logistics service that is set at the beginning of the contract and so having a proactive approach has a positive impact on all three aspects of customer loyalty (retention, expansion, referrals). Moreover, exceeding the level of targeted logistics services brings a higher marginal effect in terms of expansion and referrals on customer loyalty than when the targeted level of service is just met. However, the marginal effect of retention on customer loyalty is more significant in providing targeted service level than exceeding it.

Nonetheless, provision of logistics services over the targeted level might cause negative consequences, such as increasing future expectations, which might be difficult to fulfill without substantial changes of costs and also price (McNeilly, Barr, 2006).

Companies, including logistics providers, operate in a global world. However, it would be misleading to think that a logistics provider could set one single customer orientation strategy for all countries and regions. Customers perceive loyalty factors and behave differently in each country and so logistics providers should adjust to this.

Logistics providers should embed this aspect into their customer-oriented strategies. Related research was conducted by e.g. Cahill et al. (2010b) in which the impacts of selected customer loyalty factors were analyzed and compared for Germany and the USA. For example, exceeding the targeted logistics service in Germany has a lower impact on customer loyalty in comparison to the USA. The specifics of particular nations should not be neglected, especially the adversity to risk and change. Hence, it is highly important to identify the way logistics providers develop customer-oriented strategies and to what extent they are aware of factors directly or indirectly influencing customer loyalty currently in the Czech Republic.

\section{Methodology}

To obtain the data necessary for an informed analysis, the web pages of shipping lines, MTOs, and 3PLs were selected as data resources; in addition, input from the regional top managers (and site managers) responsible for marketing and customer service policy was sought. It must be stressed this paper itself is conceptual only. The research data are not available yet.
The forthcoming research will use qualitative casebased methods together with quantitative ones (survey). The comparative case study approach will be selected as an appropriate research method, with the intention to contribute to current theories in the field (Eisenhardt, 1989; Woodside and Wilson, 2003).

The representatives of relevant companies' top management were identified as the appropriate units for research, including their comparison. With customer service (orientation) policy being the subject of the study, surveyed companies such as shipping lines and 3PLs were selected regarding the following two criteria:

- Significant shipping line's share (by twenty-foot-equivalent (TEU) volume) in international container traffic containing the target location (the Czech Republic) as origin or destination of trade routes including the maritime portion. In the case of 3PLs, providing complex logistics service for domestic (in the Czech Republic) and foreign retail and industrial companies.

- Existence of the shipping line's subsidiary or agent office and 3PL branch in the Czech Republic.

The survey questionnaire applied in this study will be distributed to the representatives of shipping lines, MTOs and 3PL firms. In addition, open interviews will be conducted.

\section{Anticipated Results and Managerial Implications}

Firstly, upon answering the research questions and the interviews together with their analysis, the forthcoming research will aim at having a practical and applicable relevance to managers in the Czech Republic. The research outcome should identify and highlight any inefficiencies and process bottlenecks related to the strategies of shipping lines, MTOs and 3PLs in terms of customer service policy and orientation. Whilst the survey results will yield important insight related to the customer orientation of the shipping lines and 3PLs in the Czech Republic, it would not be appropriate to just generalize the results due to sample size restrictions.

Ultimately, the survey results are intended to illustrate local differences in customer orientation and marketing strategies; there is no intention within this study to provide global implications for the relevant industries of shipping and logistics.

\section{References}

Berger, P. D., Bolton, R. N., Browman, D., Briggs, E., Kumar, V., Parasuraman, A., Greed, T. (2002). Marketing Actions and the Value of Customer Assets: A Framework for Customer Asset Management. Journal of Service Research, 5 (1): 39-54.

Brooks, R. F., Lings, I. N., Botschen, M. A. (1999). Internal Marketing and Customer Driven Wavefronts. The Service Industries Journal, 26: 49-67. 
Caceres, R., CH., Paparoidamis, N., G. (2007). Service Quality, Relationship, Satisfaction, trust, Commitment and Business-to-business Loyalty. European Journal of Marketing, 41 (7/8): 836-867.

Cahill, D., L., Goldsby, T., J., Knemeyer, A., M., Wallenburg, C., M. (2010a). Customer loyalty on Logistics outsourcing relationships: An examination of the moderating effects of conflict frequency. Journal of Business Logistics, 31 (2): 253-277.

Cahill, D., L., Goldsby, T., J., Knemeyer, A., M., Wallenburg, C., M. (2010b) Logistics outsourcing performance and loyalty behaviour: Comparison between Germany and the United States. International Journal of Physical Distribution and Logistics Management, 40 (7): 579-602.

Christopher, M., Payne, A., Ballantyne, D. (2002). Relationship Marketing: Creating Stakeholder Value: Butterworth-Heinemann.

Christopher, M. (2005) Logistics and Supply Chain Management: Creating Value Added Networks: FT Prentice Hall.

Davis, B., R., Mentzer, J., T. (2006). Logistics Service Driven Loyalty: An Exploratory Study. Journal of Business Logistics 27 (2): 53-73.

Eisenhardt, K., M. 1989. Building Theories from Case Study Research. Academy of Management Review, 14 (4): 532-550.

Ganesan, S. (1994). Determinants of Long-Term Orientation in Buyer-Seller Relationships. Journal of Marketing, 58 (2): 1-19.

Gummesson, E. (2002). Practical Value of Adequate Marketing Management Theory. European Journal of Marketing, 36 (3): 325-349.

Langley, J. (2012). Third Party Logistics Study 2012, (accessed October 27, 2012),

[ available at http://www.outreach.psu.edu].

Large, R., O. (2011). Partner-specific adaptations, performance, satisfaction and loyalty in third-party logistics relationships. Logistics Research, 3 (1): 37-47.

Leung, W. (2007). The Dual Role of the Freight Forwarder: Vestfame Camera Ltd v Birkart. Journal of Maritime Law and Commerce, 38 (1): 97-109.

McNeilly, K., M., Barr, T., F.(2006). I Love My Accountants - They're Wonderful: Understanding Customer Delight in The Professional Services Arena. Journal of Services Marketing, 20 (3): 152-159.

Murphy, P., Daley, J. (1996). A Preliminary Analysis of the Strategies of International Freight Forwarders. Transportation Journal, 35 (4): 5-11.

Murphy, P., Daley, J., Hall, P. (1997). Carrier Selection: Do Shippers and Carriers Agree, or Not? Logistics and Transportation Review, 33 (1): 67-72.

Novák, R., Zelený, L., Pernica, P., Kolář, P. (2011). Přepravní, zasilatelské a logistické služby. Wolters Kluwer Česká Republika.

Pernica, P. (2004). Logistika pro 21. Století Supply Chain Management: Radix.
Sato, H. (2002). Management Strategy of Container Liner Shipping in the Age of Globalization (accessed October 25, 2012), [available at http://www.tliap.nus.edu.sg/tliap/ project_scg/docs/Reports/strategy.pdf].

Stank, T., P., Goldsby, T., J., Vickery, S., K., Savitskie, K. (2003). Logistics Service Performance: Estimating Its Influence on Market Share. Journal of Business Logistics, 24 (1): $27-55$

Steiman, C., Deshpande, R., Farley, J. U. (2000). Beyond Market Orientation: When Customers and Suppliers Disagree. Journal of the Academy of Marketing Science, 28 (1): 109-119.

Wallenburg, C., M. (2009). Innovation in Logistics outsourcing relationships: Proactive improvement by logistics service providers as a driver of customer loyalty. Journal of Supply Chain Management. 45 (2): 75-93.

Plomaritou, E. (2006). The Key Stages of Marketing Implementation in the Shipping Companies: An Empirical Research of Marketing Implementation in the Largest Tanker and Liner Companies in the World (accessed October 12, 2012), [available at http://www.scribd.com/ doc/56140560/Marketing-of-Shipping-Companies].

Plomaritou, E. I., Plomaritou, V., Giziakis, K. (2011). Shipping Marketing \& Customer Orientation: the Psychology \& Buying Behavior of Charterer \& Shipper in the Tramp \& Liner Market. Management: Journal of Contemporary Management Issues, 16 (1): 57-89.

Webster 1994: Executing the New Marketing Concept. Marketing Management, 3: 9-16.

Woodside, A. G., Wilson, E. J. (2003). Case Study Research Methods for Theory

Building. Journal of Business \& Industrial Marketing, 18 (6): 493-508.

Authors

Ing. Petr Jirsák, Ph.D. Assistant Professor

Department of Logistics, Faculty of Business Administration

University of Economics, Prague nám. W. Churchilla 4, 13067, Prague 3, Czech Republic jirsakp@vse.cz

Ing. Petr Kolář, Ph.D. Assistant Professor

Department of Logistics, Faculty of Business Administration

University of Economics, Prague nám. W. Churchilla 4, 13067, Prague 3, Czech Republic petr.kolar@vse.cz

The forthcoming research is financed by the Internal Granting Agency of the University of Economics, Prague, project no. VŠE IP300040. 